\title{
Implementation of care for the use of the extracorporeal oxygenation membrane in the COVID-19 pandemic
}

\author{
Implementação de cuidados para uso de membrana de oxigenação extracorpórea na pandemia por COVID-19
}

Implantación de cuidados para el uso de la membrana de oxigenación extracorpórea durante la pandemia por COVID-19

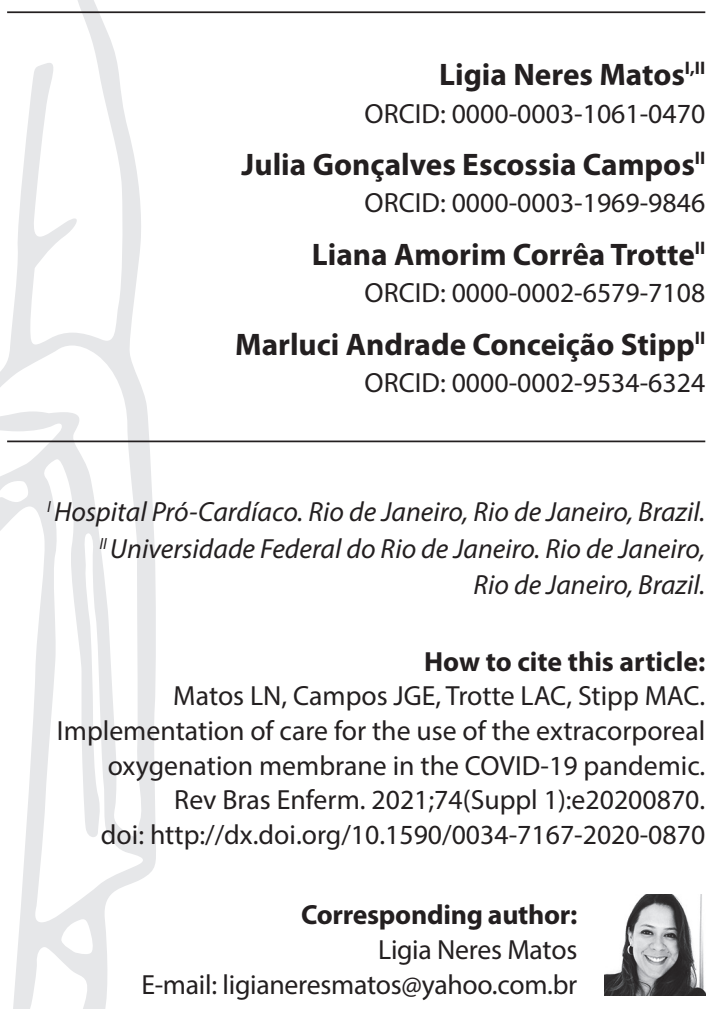

EDITOR IN CHIEF: Dulce Barbosa ASSOCIATE EDITOR: Marcia Magro

Submission: 08-03-2020

Approval: $12-21-2020$

\begin{abstract}
Objective: To report the experience of a quaternary care center on the implementation of a care program for patients with severe hypoxemic respiratory failure due to SARS-CoV-2 requiring an extracorporeal oxygenation membrane. Method: This is an experience report with a descriptive approach, analyzing the use of the extracorporeal oxygenation membrane in a quaternary care center in the city of Rio de Janeiro. Results: The planning for the use of the extracorporeal oxygenation membrane included training with the professionals and use of the components related to the adaptation of the protocol, equipment, facilities, quality and safety. Final Considerations: Planning, resource allocation and regular training of the team to offer complex interventions, in line with recommendations for good practices in the care for patients with pulmonary complications related to the new coronavirus were essential for the development of the action plan for the use of extracorporeal oxygenation membrane in this pandemic period.

Descriptors: Planning; Pandemics; Coronavirus Infections; Extracorporeal Membrane
\end{abstract} Oxygenation; Severe Acute Respiratory Syndrome

\section{RESUMO}

Objetivo: Relatar a experiência de um centro quaternário sobre a implementação de um programa de cuidados a pacientes com insuficiência respiratória hipoxêmica grave por SARS-CoV-2 com necessidade de membrana de oxigenação extracorpórea. Método: Trata-se de um relato de experiência, com abordagem descritiva, para utilização da membrana de oxigenação extracorpórea em um centro quaternário na cidade do Rio de Janeiro. Resultados: No planejamento para utilização da membrana de oxigenação extracorpórea, foram realizados treinamentos com os profissionais, utilizados os componentes relacionados a adequação do protocolo, equipamentos, instalações, qualidade e segurança. Considerações Finais: Planejamento, alocação de recursos e manutenção de treinamentos regulares com a equipe, para oferecer intervenções complexas, alinhadas com as recomendações para boas práticas no cuidado aos pacientes com complicações pulmonares relacionadas ao novo coronavírus, foram pilares fundamentais para o desenvolvimento do plano de ação na utilização da membrana de oxigenação extracorpórea neste período de pandemia.

Descritores: Planejamento; Pandemias; Infecções por Coronavírus; Oxigenação por Membrana Extracorpórea; Síndrome Respiratória Aguda Grave.

\section{RESUMEN}

Objetivo: Reportar sobre la experiencia de un centro cuaternario sobre la implantación de un programa de cuidados a pacientes con insuficiencia respiratoria hipoxémica grave por SARS-CoV-2, con necesidad de membrana de oxigenación extracorpórea. Método: Se trata de un reporte de experiencia, con enfoque descriptivo, sobre la utilización de la membrana de oxigenación extracorpórea en un centro cuaternario de la ciudad de Río de Janeiro. Resultados: En la planificación para la utilización de la membrana de oxigenación extracorpórea, los profesionales recibieron capacitación respecto a los componentes relacionados con la adecuación del protocolo, equipos, instalaciones, calidad y seguridad. Consideraciones Finales: La planificación, asignación de recursos y mantenimiento de la capacitación regular del personal para realizar intervenciones complejas de acuerdo con las recomendaciones de buenas prácticas en la atención de pacientes con complicaciones pulmonares relacionadas con el nuevo coronavirus, fueron pilares fundamentales para el desarrollo del plan de acción para el uso de la membrana de oxigenación extracorpórea en este período pandémico.

Descriptores: Planificación; Pandemias; Infecciones por Coronavirus; Oxigenación por Membrana Extracorpórea; Síndrome Respiratorio Agudo Grave 


\section{INTRODUCTION}

The new coronavirus (COVID-19) is a respiratory tract infection caused by a newly emerging coronavirus, SARS-CoV-2. On December 2019, SARS-CoV-2 was first recognized in Wuhan, China, and on March 11, 2020 COVID-19 was declared a pandemic by the World Health Organization (WHO) ${ }^{(1)}$.

In situations of mechanical ventilation failure, the WHO recommends the use of the extracorporeal oxygenation membrane (ECMO) as an additional therapy for cases of refractory hypoxemia, with the objective of allowing protective ventilation strategies ${ }^{(1)}$.

ECMO is a mechanical circulatory device with percutaneous or central access (thoracotomy) and temporary use (7 - 30 days). This system consists of access cannulas, tubes, blood pump and oxygenator ${ }^{(2)}$.

ECMO is indicated in situations of respiratory failure (venovenous) or heart failure (venoarterial). In the first strategy, two venous access sites are used: one for draining venous blood and the other for returning oxygenated blood through the membrane lung. In the second strategy (venoarterial), a venous access is used for draining and an arterial access is used for returning oxygenated blood. In both cases, systemic anticoagulation is necessary. As a hemodynamic support through the blood pump, the ECMO system is capable of offering around 4.0 liters per minute (Ipm) of oxygenated blood flow ${ }^{(2)}$. Studies on the experience of health centers at the epicenter of the disease in China, with patients with a diagnosis of viral pneumonia by SARS-CoV-2, also reported the use of ECMO in a few cases $^{(3-4)}$.

Initial experiences in China show the use of ECMO in 11.11\% of patients admitted to the Intensive Care Unit (ICU) and in 3\% of a sample of 99 patients diagnosed with COVID-19(3). According to data published on June 13, 2020 by the Extracorporeal Life Support Organization (ELSO), 1,440 extracorporeal oxygenation membrane implants have been reported in patients with suspected or confirmed COVID-19 diagnosis. About 4.29\% (49) of the implants were in Latin America, with the following factors of this population: average age of 59 years old; $72 \%$ male; diabetes mellitus was the risk factor in $13 \%$ of patients; average intubation time of 102 hours; venovenous ECMO was the type of assistance used in $91 \%$ of reported cases $^{(5)}$.

Despite of the low percentages of use of ECMO in the national and international scenario of the SARS-CoV-2 pandemic, ELSO advises on the organizational need for developing ECMO implant center processes, with the objectives of offering high quality care, using resources in a rational manner, and providing safety care for patients and health professionals ${ }^{(6)}$. This guideline justifies the development of the present experience report in a still innovative scenario of this disease in our country and considering its various clinical complications.

\section{OBJECTIVE}

To report the experience of a quaternary care center on the implementation of a care program for patients with severe hypoxemic respiratory failure due to SARS-CoV-2 requiring an extracorporeal oxygenation membrane.

\section{METHOD}

This is an experience report with a descriptive approach, analyzing a circulatory assistance center in the city of Rio de Janeiro. Initially, 14 cohort ICU beds with high efficiency particulate air (HEPA) filtering system were made available for allocation of patients with suspected or confirmed coronavirus infection. The disease was confirmed by the molecular biology test, using the reverse transcription polymerase chain reaction (RT-PCR) technique for SARS-CoV-2.

The first step in the planning and development of the care program was the elaboration of an action plan, which was built by a team of specialists with a pulmonologist, a cardiac surgeon, an infectious disease specialist, a perfusionist, a nurse in the circulatory support program, a nurse from the intensive care unit (ICU) and a physical therapist. This team was responsible for reviewing the institutional protocol for the use of ECMO and applying the adjustments suggested by the ELSO guidelines in the context of COVID-19(6). It is worth noting that, prior to the pandemic, the management of patients with ECMO met the criteria of constant updates and training of the multidisciplinary team, aiming to achieve safety and quality of care and to keep up with technological innovations.

After validating this protocol, the second stage began. It consisted of the execution of the practical training schedule for intensivists, perfusionists, nurses, nursing technicians and physical therapists in the ICU cohort. Training started on March 17, 2020 in the intensive care unit, under the coordination of the cardiac surgery and circulatory support team and aimed to train and update professionals in care planning and use of technologies in a SARS-CoV-2 pandemic scenario with patients using ECMO.

Five training sessions were held and remained constant in the unit. Training followed the institutional protocol and good internal practices to minimize the exposure of professionals to the new coronavirus (SARS-CoV-2). In addition to practical training, as another way to disseminate knowledge, a video elaborated by the circulatory assistance program nurse addressing specific points related to patients with severe hypoxemic respiratory failure due to SARS-CoV-2 requiring ECMO was shared.

During the pandemic, new professionals were admitted to the ICU cohort. Thus, training related to ECMO was maintained in an on-site model, so that safe and quality processes were still provided.

In addition to the adaptation of the protocol and training of professionals, an action plan to allocate resources related to items in the ECMO system was implemented, with the participation of the administrative team, aiming to guarantee the necessary supplies and equipment and, consequently, the rational use of available resources.

\section{RESULTS}

In line with ELSO recommendation ${ }^{(6)}$ in the pandemic period and in the absence of contraindications, ECMO was indicated in the following clinical situations: 
- $\mathrm{PaO}_{2} / \mathrm{FiO}_{2}<150 \mathrm{mmHg}$ after positioning the patient in prone position, management of mechanical ventilation with appropriate positive end-expiratory pressure (PEEP), use of neuromuscular blockade and vasodilator, if indicated. If, after these recommendations, one of these scenarios persists, for example, $\mathrm{PaO}_{2} / \mathrm{FiO}_{2}<60 \mathrm{mmHg}$ for $>6 \mathrm{~h} ; \mathrm{PaO}_{2} /$ $\mathrm{FiO}_{2}<50 \mathrm{mmHg}$ for $>3 \mathrm{~h} ; \mathrm{pH}<7.20+\mathrm{PaCO}_{2}>80 \mathrm{mmHg}$ for $>6 \mathrm{~h}, \mathrm{ECMO}$ is indicated.

- $\mathrm{PaO}_{2} / \mathrm{FiO}_{2} \geq 150 \mathrm{mmHg}$ and $\mathrm{pH}<7.20$ with $\mathrm{PaCO}_{2}>80$ $\mathrm{mmHg}$ for more than $6 \mathrm{~h}$.

The planning and use of ECMO during the COVID-19 pandemic and other outbreaks of emerging infectious diseases was described in the literature, with emphasis on components related to personnel, equipment, facilities, and communication system ${ }^{(7)}$. As shown in Chart 1, organizational components were used in our center as key points for the elaboration of the actions and the final product of this planning for the care of patients with suspected or confirmed SARS-CoV-2 infection with indication for the use of ECMO.

Chart 1 - Description of the components and their actions before and during the COVID-19 pandemic regarding the planning for the use of the extracorporeal oxygenation membrane in patients

\begin{tabular}{|c|c|c|}
\hline COMPONENTS & ACTIONS BEFORE THE PANDEMIC & ACTIONS DURING THE PANDEMIC \\
\hline $\begin{array}{l}\text { Adaptation of } \\
\text { the protocol }\end{array}$ & $\begin{array}{l}\text { Review and adaptation of the institutional } \\
\text { protocol for implantation and management } \\
\text { of ECMO in patients with suspected } \\
\text { COVID- } 19 \text { conducted by specialists of the } \\
\text { interdisciplinary team. }\end{array}$ & $\begin{array}{l}\text { Institutional protocol for } \\
\text { standardization of ECMO indications } \\
\text { and rational use of the resource. }\end{array}$ \\
\hline Personnel & $\begin{array}{l}\text { On-site training for proper use of personal } \\
\text { protective equipment and clothing. }\end{array}$ & $\begin{array}{l}\text { Training carried out on site and by } \\
\text { digital media; } \\
\text { Targeted allocation of perfusionist } \\
\text { and surgeon for cannula access; } \\
\text { Maintenance of the ECMO system } \\
\text { by perfusionist and nurse in the } \\
\text { circulatory support program. }\end{array}$ \\
\hline Equipment & $\begin{array}{l}\text { Corporate alignment with the external } \\
\text { supply of membranes and consoles/ } \\
\text { hardware. } \\
\text { Provision of personal protective equipment } \\
\text { for professionals. }\end{array}$ & $\begin{array}{l}\text { Standardization of supplies; } \\
\text { Cannulation material organized in } \\
\text { kits. }\end{array}$ \\
\hline Facilities & $\begin{array}{l}\text { Establishment of a cohort therapy unit for } \\
\text { patients with suspected or confirmed SARS- } \\
\text { CoV-2 infection. } \\
\text { Proper disposal of infectious waste. } \\
\text { Coordinated communication between the } \\
\text { ECMO team and the ICU team to optimize } \\
\text { relocation for the implants. }\end{array}$ & Cohort ICU. \\
\hline $\begin{array}{l}\text { Quality and } \\
\text { safety }\end{array}$ & $\begin{array}{l}\text { Secure fixation of cannulas - preventing } \\
\text { displacement and accidental removal. } \\
\text { Daily change of the dressings of the cannula } \\
\text { access sites with maximum barrier - } \\
\text { prevention of infection. } \\
\text { Use of heparinization protocol - prevention of } \\
\text { bleeding and thrombosis. } \\
\text { Daily inspection of the ECMO circuit and } \\
\text { membrane - prevention of system and } \\
\text { membrane failure. } \\
\text { Daily evaluation of membrane gas exchange } \\
\text {-maintenance of the oxygenation system. } \\
\text { Registering daily clinical evolution. } \\
\text { Daily multidisciplinary round with the ICU } \\
\text { team and the ECMO team. }\end{array}$ & $\begin{array}{l}\text { Standard operating procedure } \\
\text { for good practices in cannula } \\
\text { management (dressing and } \\
\text { fixation); } \\
\text { Protocols included in the } \\
\text { institutional document } \\
\text { management system; } \\
\text { Bedside checklist for monitoring the } \\
\text { circuit and operating the system. }\end{array}$ \\
\hline
\end{tabular}

Notes: ECMO: extracorporeal oxygenation membrane; UTI: unidade de tratamento intensivo.

\section{DISCUSSION}

Some changes and adjustments were necessary in some segments of institutions that used ECMO before the COVID-19 pandemic. Among these, it was necessary to adapt the ECMO protocol in patients infected with the SARS-CoV-2 virus. The planning and provision of ECMO in a pandemic situation has been discussed in the scientific community, considering the importance of the adaptation of the protocols by the leaders of the ECMO team, so that a protocol can be available to all members of the team and, in the future, in other pandemic situations ${ }^{(7)}$.

In our institution, as we already had a protocol for using ECMO, it was necessary to adapt it to meet the specificities related to COVID-19, guided by international recommendations $s^{(6)}$, which were the guideline for standardizing the concepts and establishing the criteria for indication and contraindication of therapy. As suggested by some authors, specialists must participate in the planning of a program for the use of ECMO in a pandemic situation, to guarantee the safety of the patient and of the professionals involved in the care. In this context, intensivists, ECMO specialists and infection control professionals stand out ${ }^{(8)}$.

One of the essential criteria for the protection of health professionals is personal protective equipment (PPE). In this context, the guidelines provided by WHO and other health organizations regarding precautions in relation to COVID-19 should be followed ${ }^{(1)}$. Patients with confirmed or suspected infection by the SARS$\mathrm{CoV}-2$ virus should remain in isolation so that the virus does not spread to other patients and health professionals ${ }^{(7)}$.

In the context of the current pandemic, the centers that already have ECMO installation and management services must establish criteria that can guide the following decision: transfer of the patient to a specialized ECMO center or performance of the procedure at the institution where the patient is located. In addition, the patient may also need other services within the hospital. The risks of dissemination and contamination in all these relocations need to be evaluated before the implantation of the ECMO, and disinfection measures must be applied during transportation and on objects that come into contact with the patient to minimize the risk of cross contamination ${ }^{(7)}$. 
Considering the guidelines for good internal practices that minimize exposure to the new coronavirus (SARS-CoV-2), our center does ECMO implantation at the bedside and, in this case, the percutaneous puncture strategy is more used. For arterial accesses, femoral arteries were used and, for venous accesses, femoral or jugular veins were used.

Despite the use of advanced therapies and technological resources in ICUs, there is evidence of a long period of hospitalization of patients with COVID-19 ${ }^{(5)}$, exposing them to secondary infection associated with the use of invasive devices, such as intravenous and arterial accesses, bladder catheter, orotracheal tube and ECMO cannula access sites. Regarding the access sites for the cannulas, we maintained the institutional routine of daily dressing change with maximum barrier, alcoholic chlorhexidine solution, sterile gauze and sterile secondary cover, in addition to the secure fixation and stabilization of the cannula to avoid displacement and traction in the insertion site.

Current evidence highlights the benefits of centralizing the care of these patients in implant centers and in the hands of professionals with experience and specialists due to the high demand for care and support ${ }^{(9-10)}$. In this context, the coordination of care must be a strategy for applicability and continuity of individualized care as proposed in the care program for patients using ECMO.

\section{Limitations of the study}

The limitations of this study are related to the experiences report of only one center with a care program for patients requiring short-term mechanical circulatory support, such as ECMO, during the COVID-19 pandemic. The need to highlight this experience in other centers is emphasized, as it would increase knowledge on specialized approaches in care management, which is indispensable not only in a pandemic situation.

\section{Knowledge for the area of nursing, health, or public policies}

The organizational methodology for the implementation of care for patients with COVID-19 with indication for the use of ECMO contributes with knowledge for the nursing area, as nursing professionals have become leaders in the process and coordination of patient care. This study may contribute to the development of new processes for implementing specialized care programs in a pandemic situation.

\section{FINAL CONSIDERATIONS}

Planning, resource allocation and regular training of the team to offer complex interventions, in line with recommendations for good practices in infection control and care for patients with pulmonary complications related to COVID-19, were essential for the development of the action plan for the use of ECMO in the investigated group of patients.

This data contribution to national and international registries is essential for sharing experiences from various centers throughout the pandemic. In addition, it can support robust studies that can verify the effectiveness of this therapy in the treatment of critically ill patients and patient's refractory to conventional therapy.

As in other pandemics, such as H1N1 in 2009, lessons are being learned, mainly regarding the rational use of resources, the pathophysiology of the disease and the criteria for the indication of treatment.

\section{ACKNOWLEDGMENT}

We thank the health professionals at Pró-Cardíaco Hospital who made this work possible.

\section{REFERENCES}

1. World Health Organization(WHO). Clinical management of severe acute respiratory infection (SARI) when COVID-19 disease is suspected: Interim guidance 1.2v [Internet] 2020. [cited 2020 Jun 7]. Available from: https://www.who.int/publications/i/item/ clinical-management-of-covid-19

2. Extracorporeal Life Support Organization. ELSO Guidelines for Cardiopulmonary Extracorporeal Life Support Extracorporeal Life Support Organization, Version 1.4. 2017. [Internet] 2020[cited 2020 Jun 5]. Available from: https://www.elso.org/Portals/0/ELSO $\% 20$ Guidelines\%20 General\%20All\%20ECLS\%20Version\%201_4.pdf

3. Chen N, Zhou M, Dong X, Ou Jieming, G Fengyun, Han Yan, et al. Epidemiological and clinical characteristics of 99 cases of 2019 novel coronavirus pneumonia in Wuhan, China: a descriptive study. Lancet 2020;395:507-13. https://doi.org/10.1016/S0140-6736(20)30211-7

4. Wang D, Hu B, Hu C. Clinical characteristics of 138 hospitalized patients with 2019 novel Coronavirus-Infected Pneumonia in Wuhan, China. JAMA. 2020;323(11):1061-9. https://doi.org/10.1001/jama.2020.1585

5. Extracorporeal Life Support Organization. ECMO IN COVID-19[Internet]. 2020[cited 2020 Jun 13]. Available from: https://www.elso.org/ COVID19.aspx

6. Shekar K, Badulak J, Peek G, Boeken U, Dalton HJ, Aurora L, et al. Extracorporeal Life Support Organization. COVID-19. Interim Guidelines A consensus document from an international group of interdisciplinary ECMO providers. ASAIO. 2020;66(7):707-72. https://doi.org/10.1097/ MAT.0000000000001193

7. Ramanathan K, Antognini D, Combes A, Paden M, Zakhary B, Ogino M, et al. Planning and provision of ECMO services for severe ARDS during the COVID-19 pandemic and other outbreaks of emerging infectious diseases. Lancet. 2020;518-26. https://doi.org/10.1016/ S2213-2600(20)30121-1 
8. Lewis R. Caring for critically ill patients with novel coronavirus[Internet]. Soc Crit Care Med [Internet]. 2020 [cited 2020 Jun 7]. Available from: https://www.sccm.org/getattachment/Blog/January-2020/Caring-for-Critically-III-Patients-with Novel-Coro/SCCM-Caring-for-Critically-IIIPatients-with-2019-nCoV.pdf

9. Cho HJ, Heinsar S, Jeong S, Shekar K, Li Bassi G, Jung JS, et al. ECMO use in COVID - 19: lessons from past respiratory virus outbreaks - a narrative review. Crit Care. 2020;24:301. https://doi.org/10.1186/s13054-020-02979-3

10. Lucchini A, Elli S, De Felippis C, Greco C, Mulas A. The evaluation of nursing workload within an Italian ECMO Centre: a retrospective observational study. Intensive Crit Care Nurs. 2019;55. https://doi.org/10.1016/j.iccn.2019.07.008 